\title{
DEPOPULAREA REPUBLICII MOLDOVA ÎN CONTEXTUL DECLINULUI POPULAȚIEI DIN EUROPA CENTRALĂ ȘI DE EST ${ }^{1}$
}

\author{
Olga Gagauz (C)2, dr.habilitat în sociologie, conf.cerc. \\ INCE, Centrul de Cercetări Demografice, Republica Moldova \\ DOI: https://doi.org/10.36004/nier.cdr.2021.15-01
}

\begin{abstract}
Summary
In recent decades, the population of the Republic of Moldova has been steadily declining, and this trend will persist in the coming decades. Compared to other countries in Central and Eastern Europe, the Republic of Moldova is most affected by depopulation. The present study expands evidence on depopulation in the Republic of Moldova based on the demographic projection developed by Centre for Demographic Research for 2019-2040. The results show that in the coming decades, the demographic decline would continue at a fast pace, increasing from $1.6 \%$ to $2.3 \%$ annually. The population number may decrease with $34.5 \%$ by 2040 . The population decline caused by external migration will be 776.9 thousand. The population age structure will change significantly. The emigration of younth has an important negative effect and leads to a decrease in the number of working age youth. Meanwhile the return of 50+ year old migrants from abroad leads to an increase in the proportion of older people in the population as a whole. It was concluded that the effects of depopulation are much more unfavorable than those associated with population aging. Being determined by mass migration depopulation is associated with the loss of human capital, the negative impact on quality of life, social cohesion and socio-economic development.
\end{abstract}

Keywords: depopulation, demographic projection, Republic of Moldova.

Clasificarea JEL: J11

Scăderea cronică a populației sau depopularea a devenit specifică pentru majoritatea țărilor din Europa Centrală și de Est, atât din cauza scăderii fertilității, cât și în urma migrației (Fihel, Okólski, 2019, Mileris, 2019, Dumont, 2019). Regimul demografic de scădere a populației, determinat de migrația netă negativă în majoritatea țărilor din Europa Centrală și de Est în ultimele trei decenii, este în contrast cu tendințele observate în țările din Europa de Vest, unde populația a crescut atât datorită sporului natural pozitiv, cât și datorită creșterii migraționale, care favorizează creșterea populației. Fluxurile către aceste țări au fost alimentate parțial și de migranți internaționali din Europa Centrală și de Est. Unele cercetări arată că soldul migrator net negativ este tipic numai pentru țările UE, care au cele mai puține investiții și PIB per capita (Mileris, 2019).

Conform prognozelor ONU, în deceniile viitoare declinul populației în Europa Centrală și de Est va continua cu ritmuri rapide (Tabelul 1). Republica

\footnotetext{
${ }^{1}$ Articolul este elaborat în cadrul Programului de Stat (2020-2023) 20.80009.0807.21

"Migrația, schimbări demografice și politici de stabilizare a situației".

2 (C) Ольга Гагауз, gagauzo@inbox.ru
} 
Moldova este una din cele mai afectate țări din regiune, populația căreia, către anul 2050, poate să se micșoreze cu 44,2\%, cauza principală fiind migrația în masă. Totodată, Republica Moldova rămâne una din cele mai sărace țări din regiune, PIB-ul per capita în comparație, de exemplu, cu România, fiind de aproape trei ori mai mic și de peste patru ori mai mic decât în Lituania. Modelul de creștere economică, determinată de consum și alimentată de remitențe, este puțin sustenabil, iar scăderea numărului de populație și îmbătrânirea acesteia duce la creșterea continuă a numărului de persoane cu venituri mici, dependente de pensii și alocații sociale.

Tabelul 1. Schimbările prognozate în numărul populației în țările din Europa Centrală și de Est între anii 2017 și 2050 și PIB-ul per capita, 2020

\begin{tabular}{|l|r|r|r|r|}
\hline Țara & $\mathbf{2 0 1 7}, \mathbf{m i i}$ & $\mathbf{2 0 5 0 ,} \mathbf{~ m i i}$ & \multicolumn{1}{c|}{$\begin{array}{c}\text { Scăderea } \\
\text { in \% }\end{array}$} & $\begin{array}{c}\text { PIB per capita, } \\
\text { 2020, mii \$ }\end{array}$ \\
\hline Albania & 2,93 & 2,825 & -3.6 & 5215,3 \\
\hline Belarus & 9,468 & 8,34 & -11.9 & 6411,2 \\
\hline Bulgaria & 7,084 & 5,532 & -21.9 & 9975,8 \\
\hline Croația & 4,189 & 3,865 & -7.7 & $13,828.5$ \\
\hline Republica Cehă & 10,618 & 10,21 & -3.8 & 22932,2 \\
\hline Estonia & 1,309 & 924 & -29.4 & 23027,0 \\
\hline Ungaria & 9,721 & 8,49 & -12.7 & 15899,1 \\
\hline Letonia & 1,949 & 1,25 & -35.8 & 17620,0 \\
\hline Lituania & 2,89 & 1,802 & -37.6 & 19997,6 \\
\hline Republica Moldova & $\mathbf{4 , 0 5 1}$ & $\mathbf{2 , 2 6 2}$ & $\mathbf{- 4 4 . 2}$ & $\mathbf{4 5 5 1 , 1}$ \\
\hline Polonia & 38,17 & 32,739 & -14. & 15656,2 \\
\hline România & 19,679 & 18,061 & -8.2 & 12896,1 \\
\hline Rusia & 143,989 & 129,909 & -9.8 & 10126,7 \\
\hline Serbia & 7,04 & 5,87 & -16.6 & 7666,2 \\
\hline Slovacia & 5,447 & 4,851 & -10.9 & 19156,9 \\
\hline Slovenia & 2,079 & 1,597 & -23.2 & 25517,3 \\
\hline Ucraina & 44,222 & 37,149 & -16.0 & 3726,9 \\
\hline
\end{tabular}

Sursa: International Data Base, International Programs Center, U.S. Census Bureau, PIB per capita - World bank.

Notă: Datele pentru Republica Moldova sunt prezentate împreună cu regiunea transnistreană.

Prognoza demografică elaborată de Centrul de Cercetări Demografice pentru anii 2019-2040 în baza datelor cu privire la populația cu reședința obișnuită a Republicii Moldova (fără regiunea transnistreană) prezintă aspecte mai detaliate privind dinamica demografică.

În deceniile viitoare declinul demografic va continua $\mathrm{cu}$ ritmuri rapide, scăderea anuală, conform scenariului scăzut, se va majora de la 1,6\% până la 2,3\%, numărul populației micșorându-se până la 1754,6 mii (cu 34,5\%) către anul 2040. Doar în condițiile de reducere substanțială a migrației, de 
îmbunătățire a indicatorilor sănătății populației și de creștere a fertilității, dimensiunile declinului demografic pot fi reduse, fapt confirmat de cele două scenarii. Conform scenariului mediu, numărul populației se va micșora până la 1924,9 mii (28,2\%), iar conform celui înalt - până la 2094,5 mii (cu 21,5\%).

Traiectoria schimbării numărului populației este determinată nu doar de fertilitate, mortalitate și migrație, dar și de structura pe vârste a populației în anul de bază al prognozei. Impactul acestei componente asupra dinamicii populației, alături de cele trei, este destul de semnificativ. Structura actuală a populației a acumulat o inerție negativă din cauza scăderii fertilității și creșterii gradului de îmbătrânire demografică, astfel determinând declinul demografic continuu. Persistența nivelului înalt al migrației populației tinere de vârstă reproductivă va conduce la o creștere a ritmului de îmbătrânire demografică, mai exact a proporției vârstnicilor în ansamblul populației. În anul 2040, piramida pe vârste și sexe va obține un profil neproporțional, generațiile în vârstă de 50 de ani și peste vor constitui circa jumătate din totalul populației. Ca rezultat, vârsta mediană va crește de la 37,3 ani până la 47,3 ani.

Scăderea numărului populației determinată de structura piramidei pe vârste în perioada de prognozare va constitui $6,8 \%$, sporul natural negativ va crește de la $-1,7 \%$ până la $-4,0 \%$. Scăderea populației provocată de migrația externă va constitui 776,9 mii de locuitori, inclusiv peste 200 mii de copii, care vor apărea pe lume în alte țări decât Republica Moldova.

Numărul anual de născuți depinde direct de mărimea populației feminine în vârstă de 15-49 de ani. În următoarele două decenii, generațiile mici născute la sfârșitul anilor ' 90 ai secolului trecut - începutul anilor 2000 vor constitui contingentul reproductiv principal, respectiv, numărul de copii născuți de aceste generații va fi cu mult mai mic decât cel provenit de la generațiile numeroase născute la mijlocul anilor ` 80 .

Reducerea numărului populației duce inevitabil la scăderea numărului de copii, iar migrația va continua să evolueze în calitate de factor principal al evoluției numărului de născuți. În cazul scenariului scăzut, dacă migrația tinerilor va persista în timp, numărul potențial al părinților se va micșora, respectiv, numărul de nou-născuți poate să scadă de două ori, ajungând de la 32,2 mii la 15,8 mii în anul 2040. Realizarea scenariului mediu și celui înalt, după o scădere a numărului de nașteri pe parcursul unui deceniu, poate să aducă o stabilitate relativă, în special în cazul scenariului înalt, care presupune creșterea RTF până la 2,1 copii per femeie și diminuarea migrației nete până la 0 către sfârșitul perioadei de prognozare. În acest caz, tendința de scădere se va diminua, iar după anul 2035 există o perspectivă de creștere a numărului de nașteri.

Structura generală a populației se va schimba fără precedent, conform prognozei, pentru toate trei scenarii, însă traseul scenariului scăzut va provoca cele mai nefavorabile schimbări. Proporția populației tinere în vârstă de 0-19 
ani se va micșora de la 23,9\% în anul 2019 până la 17,6\% în 2040, iar a celei în vârstă de 65 de ani și peste se va majora de la $14,2 \%$ până la 24,4\%.

Declinul populației va determina și scăderea numărului celor mai activi pe piața forței de muncă - contingentul în vârstă de 20-64 de ani. Astfel, dacă în anul 2019 efectivul acestora se estimează la cca 1659,8 mii, atunci în anul 2040 se prognozează o reducere până la 1018,6 mii. Ca proporție în totalul populației acest contingent nu se va diminua semnificativ - de la $62 \%$ până la 58,1\%, însă raportul dintre forța de muncă tânără și cea adultă se va majora în favoarea acesteia din urmă. Dacă în anul 2019 se observă o repartizare proporțională a celor trei grupe de vârstă - 20-34 de ani, 35-49 de ani și 5064 de ani, atunci către anul 2040 echilibrul va fi dereglat: ponderea grupului de vârstă de $20-34$ de ani se va reduce de la $33,9 \%$ până la $28,9 \%$, a celui de 35-49 de ani de la 32,5\% până la 24,8\%, pe când grupul de vârstă 50-64 se va majora de la $33,6 \%$ până la $46,3 \%$ (cu 12,7 p.p.).

În deceniile viitoare îmbătrânirea demografică va lua amploare, fiind alimentată de întoarcerea migranților moldoveni de peste hotare, conform tendinței stabilite în ultimii ani. Astfel, ponderea populației în vârstă de 60 și peste se va majora de la 21,3\% până la 32,3\%. Este de așteptat și o creștere considerabilă în totalul populației a persoanelor în vârstă de 70 de ani și peste. Acest contingent se va dubla, ajungând la 17,2\%. De menționat că este vorba de generațiile în viață, astfel, precizia prognozării efectivului acestora este destul de înaltă.

În Republica Moldova, fenomenul de scădere a numărului populației este observat în prezent pe o mare parte a teritoriului său, dar în special în zonele rurale. Regiunea de Nord este cea în care depopularea este deosebit de puternică, fiind determinată de creșterea mortalității ca rezultat al îmbătrânirii populației.

Contracția urbană, în special a orașelor mici, din cauza procesului de depopulare și dezindustrializare implică multiple probleme sociale, economice, spațiale, infrastructurale, precum și politice.

Dat fiind faptul că migrația este cauza principală a declinului populației, este dificil de a stopa sau de a reduce proporțiile declinului populației. Pandemia COVID-19 va avea un efect negativ asupra dinamicii principalelor procese demografice. Excesul de mortalitate a dus la o scădere a speranței de viață la naștere: $\mathrm{cu}-0,9$ ani pentru bărbați și $-1,2$ pentru femei. Numărul deceselor, în 2020, a crescut semnificativ, ducând la o creștere a scăderii naturale până la -3,8 \%o. Este de așteptat că și în anul 2021 speranța de viață la naștere va scădea, iar sporul natural negativ se va majora.

Referitor la fertilitate, există o probabilitate înaltă de scădere a acesteia ca rezultat al amânării sarcinilor în perioada pandemiei, iar înrăutățirea situației materiale a familiilor poate să alimenteze această tendință. Impactul pandemiei Covid-19 va fi resimțit doar în anul 2021.

Altă situație este cu migrația, care este dificil de prognozat. În prezent, 
putem afirma că este puțin probabil că migrația internațională va scădea. Întoarcerea migranților în perioada pandemiei Covid-19 a fost temporară. În a doua jumătate a anului 2020 fluxurile migraționale s-au reluat. Acest fenomen depinde atât de situația socioeconomică în țară, cât și de politicile migraționiste în țările europene. Luând în considerare faptul că țările europene economic dezvoltate, de asemenea, se confruntă cu îmbătrânirea populației și reducerea efectivului forței de muncă, cerința pentru forța de muncă din alte țări se va menține în continuare.

În contextul declinului populației în țările din Europa Centrală și de Est tot mai mare atenție se atrage "rezilienței demografice", care poate fi definită ca fiind capacitatea sistemelor socioeconomice locale de a rezista și a se recupera după modificările dinamicii și structurii populației (Capdevila et al., 2020). După cum menționează experții în domeniu, procesele demografice nu reprezintă amenințări directe pentru securitatea națională, iar indicatorii demografici doar relevă schimbările care au loc în efectivul și structura populației. Totodată, implicațiile economice și sociale asociate cu schimbările demografice cum ar fi sărăcia, dispariția satelor, declinul economic al regiunilor pot evolua în calitate de mecanisme de declanșare a crizelor (Sidorenko, 2019).

Efectele demografice ale depopulării sunt cu mult mai nefavorabile decât cele asociate cu îmbătrânirea populației, având un impact negativ asupra calității vieții, coeziunii sociale și dezvoltării socioeconomice. În aceste condiții, Guvernul Republicii Moldova are o sarcină foarte dificilă, care constă în asigurarea creșterii economice durabile și a nivelului de trai al populației, astfel creând un sistem economic și social rezilient. Deficitul forței de muncă atât în aspect cantitativ, cât și calitativ poate constitui un impediment în atingerea acestui obiectiv. Totodată, depopularea, în special a zonelor rurale, prezintă o provocare în ceea ce privește asigurarea infrastructurii și a serviciilor publice, începând de la transportul public până la educație și asistență medicală. Populația rămasă în zonele depopulate se simte adesea „uitată”, dezvoltând un scepticism față de instituțiile publice, iar îmbătrânirea demografică, asociată cu depopularea, afectează sistemele, preferințele și nevoile existente la nivel local.

Disparitățile teritoriale creează premisele unei dezvoltări inechitabile a zonelor urbane și rurale. Îmbătrânirea demografică reduce potențialul local de inovare și dezvoltare, deoarece persoanele în vârstă sunt, în general, mai puțin active decât cei mai tineri, iar depopularea satelor presupune și costuri mai înalte de gestionare a terenurilor agricole.

Depopularea însoțită de reducerea ofertei de forță de muncă, precum și capitalului uman și antreprenoriatului poate cauza încetinirea creșterii productivității muncii, inovațiilor etc. În acest context, politicile statului trebuie orientate spre diminuarea migrației, ca factor principal al depopulării, 
ceea ce presupune îmbunătățirea semnificativă a situației în toate domeniile vieții oamenilor.

\section{Referințe}

Capdevila, P.; Stott, I.; Beger, M.; Salguero-Gómez, R. Towards a comparative framework of demographic resilience. Trends Ecol. Evol. 2020, 35, 776786. [CrossRef]

Programul de reziliență demografică pentru Europa și Asia Centrală https://moldova.unfpa.org/sites/default/files/pubpdf/rezilienta demografica.pdf

Dumont, Gérard-François [Union européenne: dépopulation ou dépeuplement ?] [European Union: Depopulation or Population Decline?] (May 1, 2019). Population \& Avenir, $\mathrm{n}^{\circ}$ 743. [ISSN 0223-5706 ], Available at SSRN: https://ssrn.com/abstract=

Fihel, A. \& Okólski, M. (2019). Population decline in the post-communist countries of the European Union. Population \& Societies, 567, 14. https://doi.org/10.3917/popsoc.567.0001

Mileris R. (2019). "Population Migration Flows in European Union: Economic Factors and Perspective Statistical Trends," Managing Global Transitions, University of Primorska, Faculty of Management Koper, vol. 17(2 (Summer), pages 163-188. DOI: 10.26493/1854-6935.17.163-188

Sidorenko A. (2019). Demographic transition and "demographic security" in post-Soviet countries. Population and Economics 3(3): 1-22. https://doi.org/10.3897/popecon.3.e47236

Stancu, S., and O. M. Popescu. 2018. 'International Migration: The Analysis of Economic Impact in the Globalization Context.' Economic Computation and Economic Cybernetics Studies and Research 52 (4): 79-94. 